Avoimesti luettavissa osoitteessa http://journal.fi/ainedidaktiikka

\title{
Lukion historian opettajien käsityksiä esseen arviointiin vaikuttavista piirteistä
}

\author{
Hilkka Paldanius ${ }^{1}$, Sari Sulkunen ${ }^{1}$, Minna-Riitta Luukka ${ }^{1}$ ja Johanna Saario ${ }^{2}$ \\ ${ }^{1}$ Humanistis-yhteiskuntatieteellinen tiedekunta, Jyväskylän yliopisto \\ ${ }^{2}$ Monikielisen akateemisen viestinnän keskus, Jyväskylän yliopisto

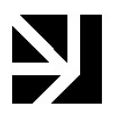 \\ Artikkelissa tarkastellaan lukion historian opettajien käsityksiä aineis- \\ topohjaisen esseen arvioinnista ja siihen vaikuttavista piirteistä \\ tiedonalan tekstitaitojen näkökulmasta. Aineisto koostuu opettajien \\ ryhmähaastatteluista ja lukiolaisten kirjoittamista aineistopohjaisista esseistä. \\ Haastattelut analysoitiin laadullisen sisällönanalyysin avulla ja esseiden kielel- \\ lisiä piirteitä systeemis-funktionaalisen kieliteorian avulla. Analyysissä keski- \\ tyttiin opettajien arvostamiin esseen piirteisiin ja niiden kielellisiin toteumiin. \\ Opettajien arvostamissa piirteissä korostuivat erityisesti sisältötiedon hallinta \\ sekä tehtävänannon noudattaminen. Aineiston käyttöön ja opiskelijan omaan \\ pohdintaan liittyviä odotuksia opettajilla oli vähemmän. Esseiden kielellinen \\ analyysi osoitti, että historian oppiaineen kielen ja sisältötiedon hallinta kietou- \\ tuvat toisiinsa: käsitteiden käyttö, informaatiorakenteen sujuvuus ja analysoiva \\ kirjoittajaääni vahvistavat vaikutelmaa sisältötiedon hallinnasta.
}

Arviointi, tiedonalan tekstitaidot, historia, essee, systeemis-funktionaalinen kieliteoria

Lähetetty: 23.9.2020

Hyväksytty: 25.1.2021

Vastuukirjoittaja: hilkka.paldanius@gmail.com

DOI: $10.23988 / \mathrm{ad} .98334$ 


\section{Johdanto}

Lukion opetussuunnitelmien perusteissa (Opetushallitus, 2015; 2019) korostetaan tiedonalan kielen ja tekstitaitojen oppimista. Jokaisessa oppiaineessa tulisi siis opiskella sille ominaisia tekstikäytänteitä eli tapoja käyttää kieltä ja tekstejä. Opetussuunnitelman perusteissa tiedonalan tekstitaidot liitetään monilukutaitoon, joka on osa laaja-alaista osaamista (Opetushallitus, 2015, s. 38; 2019, s. 58). Eri tiedonalojen - eli koulukontekstissa oppiaineiden - erilaiset tekstikäytänteet juontuvat oppiaineiden taustalla olevien tieteenalojen erilaisista tiedonmuodostuksen käytänteistä: tieteenalat eroavat muun muassa siinä, millaisiin tutkimuskysymyksiin haetaan vastausta, millaista evidenssiä voidaan käyttää, kuinka tietoa esitetään ja miten tiedonmuodostukseen liittyvää epävarmuutta ilmaistaan kielellisesti (Moje, 2015).

Tässä tutkimuksessa tarkastelemme historian tiedonalan tekstitaitoja. Historiassa tietoa muodostetaan tulkitsemalla osin ristiriitaisiakin lähdeaineistoja: niitä taustoitetaan, tulkitaan historiallisesta kontekstista käsin ja verrataan muihin aineistoihin oman tulkinnan vahvistamiseksi (Nokes, 2013). Historian opiskelussa tiedonmuodostuksen käytänteitä voidaan siten tehdä näkyväksi työskentelemällä aineistojen kanssa ja esimerkiksi kirjoittamalla niiden pohjalta. Yksi historian opiskelun tyypillistä teksteistä on essee (Sulkunen, Luukka, Saario \& Veistämö, 2019).

Vaikka essee on suhteellisen yleinen tekstilaji historian opetuksessa, ei tekstilajia tai sen kirjoittamisen opettamista lukioissa ole kovin paljon tutkittu, etenkään Suomessa. Aikaisemman suomalaisen tutkimuksen perusteella aineistopohjainen kirjoittaminen ja etenkin aineistojen tulkitseminen tuottaa opiskelijoille haasteita: historian aineistojen sisältöä toistetaan suoraan tai vain hieman muunnellen (Paldanius, 2019), tulkintoihin ei osata yhdistää historiallista kontekstitietoa eikä aineistoista havaita niiden välisiä ristiriitoja (Rantala \& van den Berg, 2015; Veijola \& Mikkonen, 2016).

Tässä tutkimuksessa tarkastelemme historian opettajien käsityksiä aineistopohjaisen historian esseen arvioinnista ja esseestä tekstinä. Tarkastelu perustuu siihen, mitä suomalaiset lukion historian opettajat kertovat arvostavansa aineistopohjaisessa esseessä ja millaisia opettajien arvioimat eritasoiset esseet ovat kielellisesti. Aineisto koostuu historian opettajien ryhmähaastattelusta sekä haastattelun pohjana olleista aineistopohjaisista esseistä. Tutkimuskysymyksemme ovat seuraavat: 1) Millaisia piirteitä historian opettajat arvostavat aineistopohjaisissa esseissä? 2) Kuinka nämä piirteet konkretisoituvat esseissä kielellisesti? Tutkimuksemme tulosten perusteella voidaan selkeyttää aineistopohjaisen esseen arvioinnin perusteita ja eksplikoida opiskelijoille, mitä esseeltä odotetaan. Tulokset hyödyttävät siis historian monilukutaidon opetuksen kehittämistä - erityisesti aineistopohjaisen esseen kirjoittamisen opetusta ja oppimista. 


\section{Systeemis-funktionaalinen näkökulma tiedonalan teksteihin}

Tutkimuksen lähtökohtana on sosiokulttuurinen käsitys kielestä, teksteistä ja tekstitaidoista. Kieltä ja tekstitaitoja lähestytään yhteisöllisesti määrittyvinä ja siten tilanteisesti vaihtelevina (Barton, 2007). Myös tiedonalan tekstitaitojen kehys nojaa käsitykseen tiedonalasta yhteisönä, jonka jäsenet neuvottelevat yhteisön tavoitteet ja toimintatavat. Näin ollen myös tiedonalojen tavat käyttää kieltä ja tekstejä muotoutuvat osana tiedonalayhteisön toimintaa (Moje, 2015). Tiedonala käsitteenä kattaa sekä oppiaineen taustalla olevan tieteenalan että oppiaineen. Asiantuntijayhteisön ja lukion oppijayhteisön tavoitteet ja toimintatavat eivät kuitenkaan ole täysin yhteneväisiä: lukion historianopetuksen tavoitteena ei ole tuottaa uutta tietoa vaan tehdä näkyväksi tiedonmuodostuksen käytänteitä, antaa opiskelijoille kokemuksia tutkimuksellisesta tiedon rakentamisesta sekä kehittää tieteenalojen kielen ymmärtämistä (Opetushallitus, 2019).

Lukion historian oppijayhteisön näkökulmasta tutkimuskysymyksemme ovat keskeisiä, sillä opettajien arvostamat esseiden piirteet liittyvät historian tiedonalan opiskelun käytänteisiin ja tekstilajeihin. Tekstilajilla tarkoitetaan jokseenkin vakiintunutta ja tunnistettavaa tekstiä, jolla on tietynlaisia tehtäviä osana sitä ympäröivää sosiaalista toimintaa (Martin \& Rose, 2008). Se, millaisessa ympäristössä ja millaisiin tarkoituksiin tekstejä käytetään, vaikuttaa tekstien kielellisiin piirteisiin. Tämä on keskeinen lähtökohta systeemis-funktionaalisessa (SF) kieliteoriassa, joka muodostaa tutkimuksemme teoreettis-menetelmällisen viitekehyksen (Halliday, 1973; suomeksi Shore, 2012). Teoriassa kielen ja tekstin ajatellaan muodostavan kolmentasoisia merkityksiä: ideationaalisia, interpersoonaisia ja tekstuaalisia. Nämä merkitystasot, eli metafunktiot, ilmenevät tekstissä yhtäaikaisesti, ja ne ovat sidoksissa tekstin kontekstiin ja käyttötarkoitukseen, eli SF-teoreettisesti ilmaistuna tekstejä ympäröivään tilannekontekstiin (Martin \& Rose, 2008, s. 11).

Ideationaalisella metafunktiolla viitataan tekstin sisältömerkityksiin eli siihen, mistä aiheesta tekstissä puhutaan (Halliday, 1973, s. 105-106). Ideationaaliset merkitykset ilmenevät esimerkiksi tekstin sanastossa ja käsitteissä. Interpersoonaisella metafunktiolla tarkoitetaan tekstiin erilaisia vuorovaikutussuhteita rakentavia kielen piirteitä, kuten kirjoittajan asennetta ja suhtautumista ilmaisevia merkityksiä (esim. vakuuttaminen, epäröinti, arviointi) (Halliday, 1973, s. 105-106). Nämä merkitykset vaikuttavat myös siihen, millainen oletettu vastaanottaja tekstiin muodostuu. Tekstuaalisella metafunktiolla taas tarkoitetaan sitä, miten teksti rakentuu ja kuinka siihen muodostuvat merkitykset yhdistyvät toisiinsa (Halliday, 1973, s. 105-106). Tekstuaalinen metafunktio ilmenee siten esimerkiksi lauseita ja virkkeitä yhdistävissä konjunktioissa, viittaussuhteissa sekä muissa tekstin teemaa ja informaatiota kuljettavissa piirteissä (Shore, 2012, s. 146-148). Metafunktioita voidaan tarkastella paitsi koko tekstin myös kappaleen sekä virkkeen ja lauseen tasoilla (Pessoa, Mitchell \& Miller, 2017). Tekstin erittely eri metafunktioiden tasoilla mahdollistaa näiden limittyvien ja yhtäaikaisten piirteiden järjestelmällisemmän kuvauksen, jolloin erilaisten tekstien ja tekstilajien tavat muodostaa merkityksiä voidaan tehdä näkyvämmäksi (Shore, 2012). 
SF-kieliteoriaa ja siihen pohjautuvaa opiskelun tekstilajien kuvausta on hyödynnetty pedagogisten mallien ja arvioinnin kehittämisessä, esimerkiksi genrepedagogiikassa, jossa tekstien ja tekstilajien tavat muodostaa merkityksiä tehdään näkyväksi ja siten myös helpommin opiskeltavaksi (Luukka, 2004; Martin \& Rose, 2008). Myös tiedonalan tekstitaitoja tutkinut Moje (2015) painottaa, että opetuksessa ja arvioinnissa on tärkeää kiinnittää huomiota kulloisenkin tekstilajin keskeisiin piirteisiin ja eksplikoida ne opiskelijoille. Tiedonalan tekstitaitojen opetuksen tueksi on kehitetty muun muassa arviointikriteeristöjä, joissa tarkastellaan kieltä ja kielenkäyttöä SF-teorian pohjalta (Humphrey, Martin, Dreyfus \& Mahboob, 2010, s. 190; Pessoa ym., 2017).

SF-kieliteoria on pohjana myös australialaisissa tutkimuksissa, joissa Caroline Coffin (2006) on luokitellut historian oppiaineessa kirjoitettuja tekstejä genreperheisiin sen mukaan, miten niissä esitetään historiallista tietoa: Historiaa selostavat (account) ja selittävät (explanation) tekstit raportoivat ja esittävät faktuaalista tietoa. Argumentoivissa (historical argument) genreissä keskiössä ovat historian tapahtumien analysointi, vertailu ja myös kyseenalaistaminen. Tässä tutkimuksessa tarkastelemamme esseet voivat lähtökohtaisesti sisältää piirteitä selittävistä ja argumentoivista teksteistä, sillä historian vastaukselta edellytetään niin menneisyyden tapahtumien kuin esimerkiksi käsitteiden hallintaa sekä kykyä arvioida tapahtumia ja käytössä olevia aineistoja kriittisesti (Veijola, 2016; Ylioppilastutkintolautakunta, 2015). Myös historian reaalikokeen vastauksia tutkinut Arja Virta (1995) esittää, että esseeltä vaaditaan tiedon itsenäistä rakentamista, ei vain menneisyyden tapahtumista kertomista. Myös australialaisissa historian genreperheiden kuvauksissa argumentoivat genret liitetään aineistopohjaisuuteen: lähteiden avulla argumentoivaan tekstiin voidaan tuoda tietoa historian tapahtumista eri näkökulmista ja siten kannattaa tai vastustaa erilaisia tulkintoja (Coffin, 2006, s. 77-82).

Coffin (2006) kuvaa historiassa kirjoitettavien tekstilajien eroja tarkasti eri metafunktioiden tasoilla. Ideationaalisesta näkökulmasta tarkasteltuna selittäviltä ja argumentoivilta historian esseiltä edellytetään oikeanlaista tiedon esittämisen tapaa: käsitteellisyyttä, määritelmiä ja asioiden suhteuttamista (Coffin, 2006). Käsitteiden käyttö ja suhteuttavat lauseet eivät kuitenkaan ole yksinomaan historian tiedonalan piirre, vaan tyypillistä yleisemminkin tieteelliselle kielelle (Halliday \& Martin, 1993) ja esimerkiksi oppikirjoille (Karvonen, 1995). Aikaisemman tutkimuksen perusteella historian esseessä erityisen kiinnostava on tekstin interpersoonainen metafunktio (Paldanius, 2020). Selostavat ja selittävät tekstit eivät välttämättä eroa tästä näkökulmasta toisistaan kovin paljoa: molemmissa tietoon suhtaudutaan pääasiassa kyseenalaistamattomana faktana, mikä näkyy esimerkiksi myönteisinä väitelauseina. Tällöin tekstiin rakentuu toteava kirjoittajan ääni (ks. Martin \& White, 2005). Molempiin voi kuitenkin sisältyä historiallisen tiedon esittämisen kannalta olennaista tapahtumien merkittävyyden arviointia (Coffin, 2006, s. 71). Selittävät ja argumentoivat tekstit eroavat taas toisistaan juuri interpersoonaisesta näkökulmasta, sillä argumentoitaessa tekstissä korostuvat historian tapahtumien arviointi sekä tulkintojen vertailu ja kyseenalaistaminen. Tällöin tekstiin rakentuu kirjoittajan ääni, joka ei esitä asioita toteavasti, vaan tulkinnallisina ja kyseenalaistettavina asioina (Martin \& White, 2005). 


\section{Tutkimuksen toteuttaminen}

Tässä tutkimuksessa selvitetään, millaisiin tekstin piirteisiin historian opettajat kiinnittävät huomiota arvioidessaan aineistopohjaista esseetä. Perustamme piirteiden luokittelun yhtäältä lukion historian opettajien näkemyksiin aineistopohjaisesta esseestä ja toisaalta tekstilajia edustavien tekstien kielelliseen analyysiin systeemis-funktionaalisen kieliteorian (Halliday, 1973; Shore, 2012) pohjalta. Keskitymme erityisesti sellaisiin opettajien haastattelussa mainitsemiin piirteisiin, jotka ovat oleellisia historian tiedonalan tekstitaitojen näkökulmasta, mutta teemme huomioita myös yleisemmistä aineistopohjaisen tekstin piirteistä.

Hyödynsimme kahta erilaista aineistoa: opiskelijoiden kirjoittamia esseitä sekä opettajien ryhmähaastatteluita. Esseistä keskusteltiin ryhmähaastatteluissa, ja niitä käytettiin myös kielellisen analyysin aineistona. Opettajat toimittivat tutkijoille kuusi eritasoista aineistopohjaista esseetä, jotka oli kirjoitettu lukuvuonna 2019-2020 osana kansainvälisten suhteiden kurssia (Opetushallitus, 2015, s. 172). Esseen kirjoittaminen aloitettiin oppitunnilla, mutta sen sai viimeistellä kotona, ja siinä sai käyttää muitakin kuin tehtävässä annettuja lähteitä. ${ }^{1}$ Kaksiosainen tehtävä perustui ylioppilaskokeessa keväällä 2017 olleeseen tehtävään, ${ }^{2}$ johon opettaja oli lisännyt arviointia edellyttävän osuuden. Tehtävän aineistona oli Hitleriä vastustaneen luterilaisen tunnustuskirkon johtajan Martin Niemöllerin (18921984) runo, joka on kirjoitettu toisen maailmansodan päätyttyä. Tehtävänanto kuului seuraavasti: "Pohdi runoa hyödyntäen, miksi Kansallissosialistinen puolue onnistui nousemaan valtaan Saksassa. Arvioi myös, miten puolueen aikaansaamaan holokaustiin tulisi suhtautua nykyään."

Ryhmähaastatteluita järjestettiin kaksi, joissa kummassakin oli läsnä kolme opettajaa sekä kaksi tutkijaa. Opettajien kokemus lukion historian opettajina vaihteli yhdestä vuodesta yli 20 vuoteen. Tutkijoiden tehtävänä oli ohjailla keskustelun kulkua ja tarvittaessa kysyä tarkentavia kysymyksiä (Pietilä, 2017). Ryhmähaastattelut järjestettiin etäyhteydellä ja tallennettiin. Ennen haastattelua opettajat arvioivat kuusi esseeaineistoon sisältyvää tekstiä asteikolla $0-20$ pistettä. Haastattelussa opettajilta kysyttiin käsityksiä onnistuneesta aineistopohjaisesta esseestä, tehtävänannon tyypillisyydestä sekä esseille annettujen pisteiden perusteluja. Tutkimuksessa on sitouduttu Tutkimuseettisen neuvottelukunnan (2019) eettisiin periaatteisiin. Näiden periaatteiden mukaisesti tutkimukseen osallistuville on annettu haastattelun litterointivaiheessa pseudonyymit eikä heitä tai heidän kouluaan voi tunnistaa.

Aineistojen analyysi aloitettiin ryhmähaastatteluista, joita lähestyttiin laadullisen sisällönanalyysin avulla. Siinä pyritään tunnistamaan aineistossa rakentuvia merkityksiä ja teemoja ja pelkistämään aineistoa (Schreier, 2013). Aluksi haastatteluista tunnistettiin sellaiset ilmaukset, joissa opettajat toivat esille arvioitaan esseiden piirteistä. Näitä ilmauksia pelkistettiin temaattisesti iteratiivisen prosessin avulla siten, että lopulta

\footnotetext{
1 Esseen suosituspituus oli 300-400 sanaa, ja opiskelijoiden kirjoittamien esseiden pituudet vaihtelivat 284 ja 408 sanan välillä.

${ }^{2}$ Historian ylioppilaskoe, kevät 2017

https://yle.fi/aihe/artikkeli/2017/02/24/2017-kevat-historia
} 
kustakin aineistossa esiin nousseesta piirteestä abstrahoitiin yksi väitelause. Väitelauseista hahmotettiin historian tiedonalan ja esseen tekstilajin edellytyksiin kiinnittyviä teemoja. Seuraavaksi väitelauseet luokiteltiin kolmeen eri kategoriaan SF-kieliteorian metafunktioiden pohjalta (Pessoa ym., 2017): Ideationaaliseen metafunktioon liitettiin väitelauseet, joissa teemana oli esseen sisältämä tieto ja aineiston liittäminen siihen sekä käytetyt käsitteet. Interpersoonaiseen metafunktioon perustuvaan kategoriaan sijoitettiin lauseet, joiden keskiössä oli argumentointi, moninäkökulmaisuus ja aineiston lähdekriittinen tarkastelu. Tekstuaalisen metafunktion kategoria taas sisälsi väitelauseet, joiden teemana oli tekstin rakentuminen ja jäsentely. Analyysin luotettavuuden ja pätevyyden varmistamiseksi kaksi eri tutkijaa kävi sisällönanalyysin tuloksena syntyneet väitelauseet ja niiden luokittelut läpi (Mayring, 2000). Lopuksi luokittelut viimeisteltiin tutkijaryhmän yhteistyönä.

Myös ryhmähaastattelujen pohjana olleet esseet analysoitiin ensin SF-teorian avulla: analyysissa keskityttiin kaikkien kolmen metafunktion rakentamiin merkityksiin. Tuloksena saatiin alustava kuvaus kunkin esseen piirteistä koko tekstin, kappaleen sekä virkkeen ja lauseen tasoilla eri metafunktioiden näkökulmista (ks. Pessoa ym., 2017). Koko tekstin tasolla siis analysoitiin, miten esseessä vastataan tehtävänannon kysymykseen, miten siinä huomioidaan tehtävänannon molemmat osat sekä miten lähteenä ollutta runoa hyödynnetään ja miten siihen viitataan. Seuraavaksi keskityimme esseiden analyysissä opettajien haastattelussa mainitsemiin piirteisiin. Analyysin tässä vaiheessa haastatteluista kerättiin sellaiset kommentit, jotka kohdistuvat selvästi yksittäiseen esseeseen tai sen tiettyyn kohtaan. Osa opettajien haastatteluissa mainitsemista piirteistä jätti tulkinnan varaa sen suhteen, mitä piirteet konkreettisesti tekstin kielen tasolla tarkoittavat. Tällaisia olivat esimerkiksi monet esittämistapaan liittyvät piirteet, kuten sujuvuus. Kielentutkijoiden tehtäväksi jäi tulkita ja konkretisoida tällaisia piirteitä. Näin saatiin tarkennettua kuvausta siitä, miten opettajien mielestä onnistuneet tai epäonnistuneet piirteet toteutuvat esseissä kielen eri merkitystasoilla.

\section{Tulokset}

\section{Opettajien arvostamat aineistopohjaisen esseen piirteet}

Esittelemme analyysimme tulokset tutkimuskysymysten mukaisessa järjestyksessä. Esitämme ensin yhteenvedon opettajien arvostamista aineistopohjaisen esseen piirteistä. Sen jälkeen pureudumme siihen, miten nämä piirteet realisoituvat esseissä kielellisesti. Opettajien arvostamat aineistopohjaisen esseen piirteet on koottu taulukkoon 1. Ne on luokiteltu sisällönanalyysin avulla neljään temaattiseen kategoriaan: tiedonalan sisältöjen hallintaan, aineiston käyttöön, tulkintojen ja pohdinnan esittämiseen sekä vastaustaitoihin. Piirteet on jaettu merkityskategorioihin SFkieliteorian metafunktioiden avulla. Lisäksi taulukkoon on merkitty jokaisen piirteen perään sulkuihin, kuinka monta kertaa se esiintyi ryhmähaastatteluissa. Temaattiset kategoriat ovat perusteltavissa aineistolähtöisesti, ja niiden avulla voi nostaa esiin analyysimme kannalta olennaisia seikkoja. Autenttisessa tekstissä temaattiset kategoriat ja metafunktiot eivät kuitenkaan ole täysin selkeärajaisia. 
Ainedidaktiikka 5(1) (2021)

Taulukko 1. Opettajien arvostamat aineistopohjaisen esseen piirteet teemoittain ja metafunktioittain

\begin{tabular}{|c|c|c|c|c|}
\hline & $\begin{array}{l}\text { Tiedonalan sisältöjen } \\
\text { hallinta }\end{array}$ & Aineiston käyttö & Oma pohdinta & Vastaustaidot \\
\hline 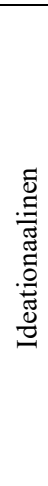 & $\begin{array}{l}\text { Esitetään relevanttia } \\
\text { historiatietoa. (18) } \\
\text { Käytetään relevantteja } \\
\text { tiedonalan käsitteitä ja } \\
\text { määritellään ne. (8) } \\
\text { Aihetta käsitellään } \\
\text { kyllin laajasti, syvälli- } \\
\text { sesti ja/tai analyytti- } \\
\text { sesti. (7) } \\
\text { Tapahtumat ajoitetaan } \\
\text { kyllin tarkasti. (1) }\end{array}$ & $\begin{array}{l}\text { Hyödynnetään } \\
\text { aineistoa. (12) } \\
\text { Aineisto liitetään } \\
\text { historiatietoon. (5) } \\
\text { Esitetään vastausta } \\
\text { tukevia aineistoesi- } \\
\text { merkkejä. (5) } \\
\text { Esitetyt aineisto- } \\
\text { esimerkit kytketään } \\
\text { laajempaan } \\
\text { ilmiöön. (5) }\end{array}$ & $\begin{array}{l}\text { Asiat kytketään } \\
\text { nykyisyyteen.(1) }\end{array}$ & $\begin{array}{l}\text { Vastataan kaikkiin } \\
\text { tehtävänannon } \\
\text { kysymyksiin. (16) } \\
\text { Aineisto on esitelty } \\
\text { esseessä antamalla } \\
\text { keskeiset lähde- } \\
\text { tiedot (tekijä, alku- } \\
\text { perä, ajankohta, } \\
\text { julkaisufoorumi). } \\
\text { (2) }\end{array}$ \\
\hline 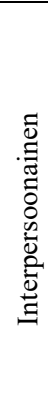 & $\begin{array}{l}\text { Esitettyjen arvioiden ja } \\
\text { näkemysten perusteena } \\
\text { on historiatietoa. (5) } \\
\text { Esitetään täsmällisiä tai } \\
\text { uskottavia arvioita } \\
\text { historian tapahtumien } \\
\text { merkittävyydestä. (4) } \\
\text { Tuodaan esille erilaisia } \\
\text { näkökulmia käsiteltä- } \\
\text { västä asiasta. (3) }\end{array}$ & $\begin{array}{l}\text { Aineistoa tarkastel- } \\
\text { laan lähdekriitti- } \\
\text { sesti (tekijä, synty- } \\
\text { ajankohta, aineis- } \\
\text { ton 'tyyppi') ja } \\
\text { tämä huomioidaan } \\
\text { tulkittaessa aineis- } \\
\text { toa. (10) }\end{array}$ & $\begin{array}{l}\text { Oma ajattelu tuo- } \\
\text { daan esille välttäen } \\
\text { liikaa ehdotto- } \\
\text { muutta, mustaval- } \\
\text { koisuutta ja yleistä- } \\
\text { mistä. (5) } \\
\text { Esitetään oma } \\
\text { näkemys tai johto- } \\
\text { päätös käsiteltä- } \\
\text { västä aiheesta. (1) }\end{array}$ & $\begin{array}{l}\text { Omat ja muiden } \\
\text { ajatukset erotetaan } \\
\text { toisistaan viittaa- } \\
\text { malla aineistoon } \\
\text { selkeästi (esim. } \\
\text { aineistossa sano- } \\
\text { taan). (3) }\end{array}$ \\
\hline 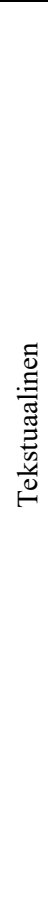 & $\begin{array}{l}\text { Asioiden käsittelyjär- } \\
\text { jestys on looginen ja } \\
\text { johdonmukainen. (6) } \\
\text { Asiat on kytketty toi- } \\
\text { siinsa ja niistä muodos- } \\
\text { tuu yhtenäinen koko- } \\
\text { naisuus. (3) } \\
\text { Esseen sanavalinnat ja } \\
\text { ilmaukset ovat historiaa } \\
\text { käsittelevään asiateks- } \\
\text { tiin sopivia. (2) }\end{array}$ & $\begin{array}{l}\text { Esseessä viitataan } \\
\text { aineistoon asian- } \\
\text { mukaisesti (esim. } \\
\text { teoksen nimellä, } \\
\text { kirjoittajan sukuni- } \\
\text { mellä). (9) }\end{array}$ & & $\begin{array}{l}\text { Esseessä on toi- } \\
\text { miva lopetus: siinä } \\
\text { käsitellyt asiat kyt- } \\
\text { ketään nykyisyy- } \\
\text { teen tai esitetään } \\
\text { jokin johtopäätös. } \\
\text { (6) } \\
\text { Esseessä on toi- } \\
\text { miva aloitus: siinä } \\
\text { esitellään tehtä- } \\
\text { vänannon kannalta } \\
\text { keskeiset käsitteet, } \\
\text { asiat ja aineisto. } \\
\text { (5) } \\
\text { Teksti on sujuvaa. } \\
\text { (4) } \\
\text { Esseessä on selkeä } \\
\text { rakenne ja kappale- } \\
\text { jako: alku, käsitte- } \\
\text { lyosa ja lopetus. } \\
\text { (4) } \\
\text { Esseen kieli on } \\
\text { huoliteltua. (1) }\end{array}$ \\
\hline
\end{tabular}

Opettajat toivat haastattelussa esille useita tiedonalan sisältöjen hallintaan ja yleisiin vastaustaitoihin liittyviä piirteitä. Opettajien arvostamissa piirteissä korostuivat sisältötiedon hallintaan liittyvät seikat, kuten relevantin historiatiedon esittäminen (18 mainintaa) ja relevanttien tiedonalan käsitteiden käyttäminen ja määritteleminen (8 mainintaa). Myös tehtävänannon noudattaminen oli opettajista tärkeää: etenkin tämän esseen kaksiosaisen tehtävänannon yhteydessä korostui kaikkiin tehtävänannon 
kysymyksiin vastaaminen (16 mainintaa). Myös aineistojen käyttö oli opettajien mukaan olennaista aineistopohjaisessa esseessä (12 mainintaa). Tiedonalan tekstitaitoihin liittyvistä tiedonmuodostuksen ja historiallisen ajattelun käytänteistä puolestaan painottui aineiston lähdekriittinen tarkastelu ja tulkinta (10 mainintaa). Oman pohdinnan esittämiseen liittyviä piirteitä oli vähiten (7 mainintaa).

Yksittäisten piirteiden esiintymistaajuudesta voi päätellä, millaisia piirteitä historian opettajat erityisesti arvostavat aineistopohjaisessa esseessä. Mainintojen lukumäärien perusteella sisältötiedon hallintaan liittyvät piirteet näyttävät painottuvan. Piirteiden lukumäärä kussakin teemassa voi heijastaa opettajien arvostamien piirteiden painotuksia, mutta kertoa myös - tai ennen kaikkea - opettajien valmiudesta yksilöidä arvostamiaan piirteitä. Jotta saisimme tarkemman kuvan siitä, mitä opettajat arvostamillaan piirteillä konkreettisesti tarkoittavat, tarkastelimme haastatteluja ja opettajien arvioimia esseitä rinnakkain. Analysoimme erityisesti sisältöjen hallinnan, aineistojen käytön ja oman pohdinnan kielellisiä realisoitumia metafunktioiden avulla.

\section{Tiedonalan sisältöjen hallinta}

Opettajat mainitsivat ryhmähaastatteluissa useimmin relevantin historiatiedon esittämisen (taulukko 1), joka on keskeinen tapa osoittaa tiedonalan sisältötiedon hallintaa. Esimerkissä 1 Rami kommentoi esseetä B siitä näkökulmasta, mitä tehtävänannon kannalta relevanttia tietoa siinä on esitetty. Tähän kategoriaan sijoitetuissa aineistokohdissa oli tavallista myös se, että opettajat kuvasivat esseiden tiedollisia puutteita. Tätä havainnollistaa esimerkki 2, jossa Marko pohtii, mitä sisällöltään suhteellisen onnistuneeseen esseeseen vielä olisi voinut lisätä.

1. täs on sitten aika kivasti kuitenkin esitelty tätä Saksan taloustilannetta tästä kakskyt kolkytluvun vaihteesta ja Hitlerin toimintaa on ja tota ja vaalityötä ja niitä lupauksia (Rami esseestä B)

2. tiedollisesti niinkun jos ois ottanu vaikka niinkun propagandan jollakin tavalla esiin sen niinkun - - tietosodankäynnin ja tällasen niinkun natsien valtaannousussa niin sillon tois ollu tavallaan se ois nostanu mun mielest sen arvoo sit taas kohtalaisen paljonkin koska sit se ois niinkun vielä paremmin tullu sellasta tiedollisesti että oo koo sil on niinkun isot palaset aika kivasti kohdallaan tässä. (Marko esseestä D)

Tiedonalan sisältöjen hallinnassa opettajat sanoivat arvostavansa myös tiedonalan käsitteiden käyttämistä ja määrittelemistä sekä kyllin laajaa tai syvällistä aiheen käsittelyä. Tenho kuvasi käsitteisiin liittyviä odotuksia seuraavasti:

3. sais aina lisää pisteitä jos osais määrittää ne käsitteet tai niinkun käyttää niitä vähän monimutkasempia käsitteitä siinä samantien.

Haastatteluaineiston ja esseiden tarkastelu rinnakkain osoittaa, että kieli ja tiedonalan sisältöjen esittäminen näyttävät kietoutuvan yhteen. Opettajien huomio kiinnittyi erityisesti siihen, millaista käsitteistöä tekstissä hyödynnetään ja miten asiat kytketään toisiinsa, toisin sanoen tekstin ideationaalisiin ja tekstuaalisiin piirteisiin. Seuraava esimerkki 4 on esseestä B, jota kehuttiin niin sisällön kuin esitystavankin puolesta. Esseestä sanottiin 
muun muassa, että se on erittäin sujuva - - perinteinen tämmönen klassinen historiavastaus (Tomi) ja jotenkin sellanen historiallisen tekstin tuottaminen on sillein ihan hyvällä tasolla (Vappu). Esseen B ideationaalisten eli sisältömerkitysten tarkastelu havainnollistaa, kuinka historiallisen tekstin tuottaminen kietoutuu historian sisältöjen esittämiseen.

4. Vuosina 1930-1933 maailmanlaajuinen taloudellinen lama oli vaikuttanut vahvasti Saksaan. Miljoonat ihmiset olivat työttömiä sekä Saksaan iski hyperinflaatio. Tällainen taloudellinen tilanne teki Saksan poliittisesti epävakaaksi. Poliittisen epävakauden seurauksena Saksassa on yritetty tehdä useita vallankaappauksia vuosina 1920, 1921 ja 1923. Hitlerin ensimmäinen vallankaappaus epäonnistui, jonka seurauksena Hitler tuomittiin törkeästä maanpetoksesta vankilaan. (Essee B)

Esimerkissä 4 hyödynnetään historiallisia ja poliittisia käsitteitä, jotka ovat teknisluontoisia ja abstrakteja (esim. hyperinflaatio, vallankaappaus) ja historian käsitteille tyypillisesti sisältävät paljon aikakauteen ja poliittiseen tilanteeseen yhdistyvää tietoa (Halldén, 1998). Lisäksi toiminta on abstraktia ja asioita suhteutetaan toisiinsa: Verbit eivät kuvasta konkreettista toimintaa, vaan ne keskittyvät asioiden välisten suhteiden ja muutosten kuvaukseen, jossa inhimillisiä toiminnan aiheuttajia ei nimetä (oli vaikuttanut, teki, oli yritetty tehdä, tuomittiin). Varsinainen toiminta on pysäytetty eli se ilmaistaan paljon tietoa sisäänsä lataavilla substantiivilausekkeilla, jotka käsitteiden ohella nostavat tekstin abstraktiotasoa (esim. poliittinen epävakaus, Hitlerin ensimmäinen vallankaappaus).

Ideationaalisesta näkökulmasta tarkasteltuna esseessä B esitetään tehtävänannon aihetta taustoittavaa historiatietoa ja aihetta käsitellään analyyttisesti, mitä opettajat pitivät haastatteluissa hyvän historian esseen piirteinä (taulukko 1; esimerkit 1 ja 2). Käsitteiden käyttö ja suhteuttavat lauseet ovat kuitenkin tyypillisiä yleisemminkin tieteelliselle kielelle (Halliday \& Martin, 1993). Historian tekstille ominaisten käsitteiden käyttö ei yksistään teekään tekstistä tiedonalan sisältöjen esittämisen näkökulmasta onnistunutta, sillä opettajat kiinnittivät haastatteluissa huomiota myös tekstin sujuvuuteen. Esimerkiksi Suvi toteaa esimerkin 4 esseestä, että mun mielestä jos pystyy kirjottamaan sujuvaa asiatekstiä niin siitä ansaitsee kyllä muutaman pisteen. Opettajat voivat viitata sujuvuudella monenlaisiin tekstin piirteisiin, mutta tekstintutkimuksen näkökulmasta sujuvuuden tarkastelussa oleellista on informaation kulku: se miten tekstissä siirrytään lauseesta ja virkkeestä toiseen ja kuinka lukijalle uusi ja vanha tieto kytketään toisiinsa (Shore, 2008). Esseen B kussakin kappaleessa on selkeä oma teemansa, jota elaboroidaan siirtymällä loogisesti virkkeestä toiseen. Tämä näkyy esimerkissä 4 siten, että kunkin virkkeen alku jatkaa edeltävän virkkeen lopussa mainittua asiaa ja voi myös selittää sitä (esim. tällainen taloudellinen tilanne avaa edellisen virkkeen lopun hyperinflaatiota). Runsas käsitteiden käyttö yhdistettynä etenevään informaatiorakenteeseen saattaakin osaltaan vaikuttaa siihen, että esseestä B syntyi opettajille lähteitä sellaisenaan toistava tai plagioiva vaikutelma: tekis vähän mieli syöttää johonkin plagioinnin tarkistusohjelmaan (Suvi). 


\section{Ainedidaktiikka 5(1) (2021)}

Näiden tekstuaalisten piirteiden lisäksi asiatekstityylin rakentumiseen liittyvät myös interpersoonaiset merkitykset: niiden näkökulmasta esimerkki 4 muodostuu pääosin myönteisistä väitelauseista, joiden avulla esitetty tieto vaikuttaa esimerkiksi oppikirjalle tai tietotekstille tyypillisesti toteavalta ja faktuaaliselta. Siinä ei esitetä kirjoittajan suhtautumista, kyseenalaisteta, oteta kantaa tai viitata toisiin lähteisiin, joten tekstiin rakentuu tietäjän rooli (ks. Shore, 2012, s. 179). Kertoville historian tekstilajeille ominaisesti essee sisältää myös historiallisten tapahtumien merkittävyyden arviointeja, joita ei kuitenkaan esitetä eksplisiittisesti kirjoittajan itsensä tekeminä (ks. esim. 4 vahvasti, useita) (ks. Coffin, 2006, s. 57).

Vaikka esimerkissä 4 historiatiedon esittäminen ja tekstin sujuvuus kietoutuvat toisiinsa, opettajat osoittivat haastatteluissa arvioivansa asiasisältöä ja tekstin kielellisiä piirteitä myös erillisinä asioina: Hyvin kirjoitettu teksti voi myös jonkin verran kompensoida esseen tiedollisia puutteita. Opettajat huomauttivatkin siitä, kuinka puhekielisyydet ja sopimattomat sananvalinnat ovat häiritseviä esseissä. Seuraava esimerkki 5 on esseestä C, joka ei esimerkin 4 tapaan edusta vastaukselta odotettavaa asiatekstin tyyliä. Rami totesi esseestä, että täs tosiaan oli pielessä kanssa että tää oli niinkun tällasta puhekielisyyttä joka niinkun jos sen historiavastauksen tulis olla sellasta asiatekstiä .

5. Kansallissosialistinen työväenpuolue hallitsi Saksaa 19331945, jolloin Adolf Hitler oli Saksan diktaattori ja kaikki valta oli silloin luonnollisesti hänellä ja hänen puolueellaan. Kyseinen puolue nousi valtaan suuren ihmisjoukon tukemana. NSDAP oli levittänyt suurta propagandaa sekä kertonut selkäänpuukotusmyyttiä, millä siis tarkoitetaan sitä, että ensimmäisen maailmansodan häviämisen syinä olivat pääosin petturijuutalaiset ja vasemmistolaiset. Saksa koki kovaa taloudellista ahdinkoa sekä nöyryytystä ensimmäisen maailmansodan jälkeen, siispä natsit keksivät syyttää juutalaisia sekä siinä kaiken lomassa keksivät, että minkälaisen saksalaisen ihmisen tulisi olla. Hitler vakuutti, että saksalaiset olisivat ylempiarvoisia sekä niin sanotusti rodultaan muita parempia. Hitler sanoi saksalaisia arjalaisiksi. Arjalaisuutta ylistettiin ja sitä pidettiin ylimpänä rotuna. (Essee C)

Esimerkissä 5 on asiatyylistä poikkeavien sananvalintojen (petturijuutalaiset, natsit keksivät syyttää) lisäksi huomionarvoista se, että toisin kuin esimerkissä 4, lauseiden toimijoina ovat pääasiassa ihmisryhmät, jotka on nimetty historian käsitteitä käyttäen (kansallissosialistinen työväenpuolue, NSDAP, natsit), tai nimeltä mainitut historialliset henkilöt (Hitler). Esimerkissä keskitytään kuvaamaan konkreettisesti tapahtumia erilaisten, usein verbaalista tai mentaalista toimintaa kuvastavien verbien avulla (hallitsi, keksivät, vakuutti, sanoi). Toimijoiden ja toiminnan esitystavat vaikuttavat tekstin ideationaalisiin eli sisältömerkityksiin: vaikka tekstissä hyödynnetään historian sanastoa, sen kieli ei ole esimerkkiin 4 verrattuna yhtä abstraktia, sillä siinä esitellään asioiden välisiä suhteita hyvin niukasti ja historiassa tärkeät suuremmat linjat jäävät mainitsematta. Haastatteluissa esseetä kommentoitiinkin sanomalla, että siinä on oikeita juttuja hyviä kyllä mut sit se jää vähän sellaseks pintapuoliseks (Marko). 
Vaikutelma pintapuolisuudesta voi johtua siitä, että teksti keskittyy puolueen ja Hitlerin toimien kuvaamiseen eikä nosta käsittelyä abstraktimmalle ja rakenteelliselle tasolle (ks. Halldén, 1998).

Esimerkit 4 ja 5 havainnollistavat, kuinka sisältöjen hallinta ja esitystapa kietoutuvat yhteen. Sujuvuutta ja oikeanlaista historian kielen hallintaa ei voikaan täysin irrottaa siitä, millaisena tiedonalan sisältöjen hallinta näyttäytyy tekstissä. Sujuvuus ja johdonmukaisuus syntyvät kielen piirteiden analyysin perusteella oikeanlaisesta käsitteiden käytöstä, joka yhdistyy loogiseen informaation etenemiseen sekä selittävälle tekstille ominaiseen toteavaan kirjoittajaääneen (Coffin, 2006). Tämä yhdistelmä tuottaa vaikutelman historian sisältötiedon hallinnasta.

\section{Aineistojen käyttö}

Opettajien kolmanneksi useimmin mainitsema piirre oli aineiston hyödyntäminen. Se sijoittuu taulukossa 1. kategoriaan aineiston käyttö mutta sivuaa myös vastaustaitoja, sillä kysymyksessä on tehtävänannon noudattamiseen liittyvä seikka. Opettajat pitivätkin aineiston käyttöä ehdottomana vaatimuksena, koska kyseessä on aineistopohjainen tehtävänanto. Haastattelussa muun muassa Tomi ja Tenho toivat esille, kuinka aineiston hyödyntämättä jättäminen on iso virhe ja esseestä on pakko sitten antaa huono numero. Toisaalta hyvin vähäinenkin aineiston käyttö oli riittävää. Haastatteluissa tämä ilmeni muun muassa esimerkkien 6 ja 7 kaltaisissa Ramin kommenteissa, joissa aineistoa tulee hyödyntää pikkasen ja esseen C ansioksi voi katsoa sen, että runoa käsitellään hieman.

6. sitten just se aineiston käsittely että sitä dokumenttia pitää jotenkin niinkun pikkasen ottaa esille siinä vastauksessa on aina sillein että siitä jää pisteitä puuttumaan jos sitä dokumenttia ei oo käsitelty ja jos siihen ei oo viitattu (Rami tehtävänannosta ja tekstilajista)

7. hieman sitä runoa jälleen kyllä käsitelty - - et sitä on käsitelty sitä runoa ja se on se on plussaa (Rami esseestä C)

Opettajat mainitsivat suhteellisen usein kaksi muutakin aineiston käyttöön liittyvää piirrettä: he arvostivat lähes yhtä paljon aineiston lähdekriittistä tarkastelua (taulukko 1, 10 mainintaa) sekä asianmukaista viittaamista aineistoon (9 mainintaa). Aineiston lähdekriittisellä tarkastelulla opettajat tarkoittivat aineiston tekijän, syntyajankohdan ja julkaisupaikan tunnistamista ja niiden huomioimista aineiston tulkinnassa (esimerkki 8).

8. myös kannattaa niinkun tämmösiä perus lähdekriittisiä niinkun huomioita voi tehdä jos niinkun pystyy ja osaa että et niinkun mitä missä se on niinkun se teksti tai kuva tai missä se on julkastu ja miten se nyt sitten vaikuttaa siihen niinkun asiaan (Vappu tehtävänannosta ja tekstilajista)

Opettajien mukaan myös aineiston tekstilaji tulisi huomioida tulkinnassa. Rami painottaa tätä esimerkissä 9: esseiden kirjoittajien tulisi huomioida aineiston fiktiivinen luonne. Rami tuo esille, että tätä ei kukaan arvioitujen esseiden kirjoittajista ollut osannut tehdä. Opettajien mukaan kyseessä ei kuitenkaan ollut vieras tehtävänanto, sillä historian opetuksessa aineistoina voidaan käyttää monenlaisia tekstejä: kirjoitettuja ja visuaalisia tekstejä, faktuaalisia ja fiktiivisiä tekstejä. Toisaalta fiktiivisiä tekstiaineistoja 
on käytetty suhteellisen harvoin esimerkiksi ylioppilaskokeessa (Puustinen, Paldanius \& Luukka, 2020). Opettajat pitivät lähdekriittistä otetta esseissä kaiken kaikkiaan vaatimattomana: esimerkiksi runoa saatetaan lukea kuin tietotekstiä.

9. kukaanhan ei oikein ollu tässä näissä yhessäkään vastauksessa niinkun kiinnittänyt kunnolla huomiota siihen että toi on runo ja - - toi ei pidä niinkun sinäänsä paikkaansa ollenkaan toi runo se on vaan niinku metafora siitä mutta että ne oli ottanut sen niinkun jotenkin kirjaimellisesti. (Rami tehtävänannosta ja tekstilajista)

Haastattelujen perusteella esseissä aineiston käyttöön liittyviä haasteita olikin kahdenlaisia: aineistoa ei joko hyödynnetty lainkaan tai sen käsittelyä ei osattu yhdistää historiatietoon eikä aineistoa analysoida kriittisesti. Haasteet kietoutuivat siis ideationaalisten ja interpersoonaisten merkitysten ilmaisemiseen. Seuraava esimerkki 10 on katkelma esseestä $C$, jossa on haastattelujen perusteella onnistuttu hieman muita esseitä paremmin runon käsittelyssä:

10. Martinin runon sanoma on natsismin vastustaminen. Martin oli Hitleriä vastustanut mies, joka kirjoitti runon osakseen sen takia, että kertoi mitä toisinajattelijoille ja natseja vastustaneille ihmisille käy. Hän myös mainitsee "Sitten he tulivat hakemaan minua - eikä jäljellä ollut enää ketään, joka olisi voinut sanoa vastaan." Tämä jo itsessään tarkoittaa sitä, että kun hänet viedään natsien toimesta, ei ole enään muita toisinajattelijoita, jotka pystyisivät olemaan erimieltä Hitlerin kanssa. Tällaisen kuvan ainakin itse saan. (Essee C)

Esimerkin 10 ensimmäisessä virkkeessä tulkinta runon sanomasta esitetään analyyttiselle kielelle ominaisella tavalla: esityksessä hyödynnetään luokittelevaa verbiä ja toiminnan pysäyttämistä substantiiviksi (sanoma on natsismin vastustaminen) sen sijaan, että se kerrottaisiin konkreettisen verbin avulla (vrt. Martin vastustaa). Vastaustaitojen näkökulmasta tarkasteltuna esimerkissä on myös selkeästi erotettu kirjoittajan oma ääni viittauksilla, joita voi pitää tulkintaa esittävinä (tämä jo itsessään tarkoittaa sitä). Aineiston käytön näkökulmasta erityisesti esimerkin toinen virke on aineistossa poikkeuksellinen, sillä siinä eksplikoidaan runon kirjoittajan taustoja, jotka vaikuttavat sen tulkintaan. Vaikka tiedot runoilijasta (Hitleriä vastustanut mies) on poimittu suoraan runoa esittelevästä tehtävänannosta, niiden esittäminen on kirvoittanut opettajista Suvin kommentoimaan esseessä olevan hieman lähdekritiikkiäkin siinä mielessä, että on pohdittu, kuka Martin Niemöller on. Historian tekstitaitojen näkökulmasta onnistuneena voi pitää sitä, että tietoa kirjoittajan taustoista hyödynnetään runon sanoman esittämisessä (kertoi mitä toisinajattelijoille ja natseja vastustaneille ihmisille käy). Aineiston tuottamiskontekstin eksplikointia voi siten pitää askeleena kohti aineiston tiedonalakohtaista tulkintaa.

Opettajat kuitenkin mainitsivat aineiston käsittelyn puutteena esimerkin 10 kohdalla sen, että runon käsittely on pinnallista eikä sanoman tulkinnassa huomioida runoa tekstilajina. Esimerkiksi Vappu totesi 
esseestä C näin: ongelmana ehkä ollu se et viel ois voinu päästä syvemmälle siihen aineistoon. (Ks. myös esim. 9.) Opettajien mainitsema pinnallisuuden vaikutelma voi johtua siitä, ettei runon käsittelyyn yhdistetä opettajien odotusten mukaisesti historian kontekstitietoa. Esimerkkiin tuodaan runosta suora sitaatti, ja runon tarkoituksen tulkinta jää kuitenkin sisällön sanoittamiseksi toisin sanoin: siinä pysytään runon maailmassa ja runon toimijoissa (ryhmät haettiin, hänet viedään).

Haastatteluissa peräänkuulutettu analyyttisyys (7 mainintaa), runon lähdekriittinen tulkinta (10) sekä runon liittäminen laajempaan historialliseen kontekstiin (5) ei opettajien mukaan toteutunut kovin hyvin yhdessäkään esseistä. Lisäksi haastatteluissa nousi esiin esimerkin 10 kaltainen ongelma, että fiktiivistä runoa tulkitaan ikään kuin tietolähteenä. Myös muutoin parhaaksi arvioidussa esseessä D on tämä ongelma. Seuraava esimerkki 11 on kyseisestä esseestä. Siinä aineisto mainitaan kahdessa kohdassa siten, että runon sisältö integroidaan osaksi esseessä kerrottavaa tarinaa Hitlerin noususta:

11. Hitlerin noustua valtaan Saksa alkoi muuttua nopeasti. Ei mennyt kuin muutama kuukausi ennen kuin ensimmäiset keskitysleirit oli jo perustettu. Aluksi keskitysleireille vangittiin poliittisia vastustajia. Tässä vaiheessa runossa tultiin hakemaan ammattiyhdistysaktivisteja, jotka vastustivat Hitlerin toimia. Samaan aikaan alettiin kuitenkin vainoamaan myös juutalaisia. Runoilija kertoo, kuinka juutalaisia tultiin hakemaan, eikä hän vieläkään vastustellut. Sillä, ettei kukaan ole pitämässä runoilijan puolia, kun hänet itse lopulta haetaan, saatetaan viitata siihen, kuinka paljon ihmisiä tapettiin tai vangittiin natsien takia. Toisaalta ihmiset saattoivat olla peloissaan, eivätkä sanoneet vastaan. (Essee D)

Esimerkissä 11 on selkeitä kielellisiä merkkejä siitä, että lähdettä pyritään tulkitsemaan ja liittämään historialliseen tietoon (saatetaan viitata siihen). Historialliseen tietoon liittäminen toteutuu esseessä kuitenkin siten, että aineistosta ikään kuin yritetään löytää tietoa historiallisista tapahtumista tulkintaa runon tekstilajista ja tuottamiskontekstista ei tehdä. Myös esseen D puutteeksi esitetään se, että aineistoon olisi voinut tarttua tarkemmin viedä sitä sen käyttöä eteenpäin (Vappu). Haastatteluissa kommentoitiin suhteellisen taajaan viittaustapoihin liittyviä puutteita. Toisaalta pelkkä asianmukainen viittaustapa ei yksinään riitä. Esimerkiksi esseen A kirjoittaja hallitsee erilaisia viittaustapoja, mutta esseetä kritisoitiin siitä, että siinä runoa ei tulkita: Esseessä kerrotaan mitä siinä runossa tapahtuu mutta että siinä ei päästä runon taakse että mitä sillä runolla sanotaan (Tomi). Asianmukainen viittaus runoon tai kyky referoida sitä ei siis vielä täytä tiedonalalähtöisen historianopetuksen tavoitteita aineistojen käytöstä (ks. myös Paldanius, 2019).

Yllä analysoidut esimerkit osoittavat, että kirjoittajat hallitsevat ensinnäkin niitä kielellisiä keinoja, joiden avulla aineisto tuodaan osaksi omaa tekstiä eli teknisiä viittaustaitoja, sekä toiseksi sellaisia keinoja, joiden avulla opettajienkin arvostama oman tulkinnan esittäminen ja sen erottaminen muusta tekstistä olisi mahdollista (esim. voisi päätellä; tämä jo itsessään tarkoittaa sitä; saatetaan viitata siihen). Aineiston käsittelyyn ei kuitenkaan osata tuoda mukaan johtopäätöksiä ja tulkintaa, jossa 
huomioitaisiin historian tekstitaitojen näkökulmasta keskeisesti aineiston tuottamiskonteksti sekä relevanttia historian kontekstitietoa.

\section{Oma pohdinta}

Kolmanneksi arviointiin vaikuttavaksi seikaksi muodostuu haastattelujen perusteella se, miten esseissä tuodaan esiin kirjoittajan omaa pohdintaa. Pohtivaa lähestymistapaa odotetaan monissa historian tehtävänannoissa, mutta se voi olla opiskelijalle melko vaikeasti hahmottuva tekstin ominaisuus. Pohdinta voi toteutua opiskelijan vastauksissa esimerkiksi tietynlaisena kirjoittajan oman äänen esittämisenä ja tekstin moninäkökulmaisuutena (esim. Juvonen, 2014, s. 72; Paldanius, 2020, s. 50-51).

Oman pohdinnan esittämisestä oli haastatteluissa vähemmän kommentteja kuin muista teemoista (ks. taulukko 1), mutta kategoriaan kuuluvat väitteet ovat kuitenkin keskeisiä aineistopohjaisen esseen arvioinnin näkökulmasta. Esimerkissä 12 Marko esittää, että aineiston käyttöön liittyvä pohdinta erottaa korkeimman arvosanan saavat opiskelijat muista myös ylioppilastutkinnossa. Pohdinta pitää kuitenkin tuoda esiin oikealla tavalla. Siinä tulisi välttää liiallista ehdottomuutta ja mustavalkoisuutta (taulukko 1, 5 mainintaa) ja vastauksen tulisi myös perustua historialliseen tietoon (5 mainintaa), kuten Marko painottaa (esimerkki 12).

12. mikä erottaa sellasen jolla on mahollisuus kirjottaa vaikka ee tai ällä historiasta. niin kyl sen aika nopeasti heti oikeestaan näkee siinä kun se lähdettä käsittelee koska se ei oo mustavalkosta vaan siel on harmaan sävyjä. ja se tavallaan poimii ne osa-alueet ja osaa lukea rivien välistä ja tietenkin käyttää sitä historiallista tietoa. (Marko tekstilajista ja tehtävänannosta)

Lisäksi pohdinta näyttäytyi opettajien haastatteluissa kirjoittajan oman äänen ja tulkintojen esittämisenä. Esseitä kritisoitiin, jos niistä puuttui analyyttisyys, joka taas näyttäytyi vastakohtana pelkälle historiatietojen kuvailulle. Haastattelut tukevatkin aikaisempaa tutkimusta siitä, että opiskelijoille voi tuottaa haasteita löytää historian esseeseen ja asiatekstiin sopiva tapa ottaa kantaa ja pohtia tehtävänannon kysymystä (ks. Paldanius, 2020). Oma näkemys voidaankin haastattelujen mukaan ilmaista liian voimakkaasti, kuten seuraavassa esimerkissä 13:

13. Toisen maailmansodan aikana natsit harjoittivat rotuoppia sen äärimmäisimmässä ja hirveimmässä muodossa. Natsit rakennuttivat keskitysleirejä eripuolille Eurooppaa, joissa he pitivät juutalaisia, homoja, vammaisia sekä muita alempiarvoisia ihmisiä. Natsipuolueen toimeenpantu lopullinen ratkaisu oli käytännössä suureksiosaksi juutalaisiin kohdistunut joukkotuho, jota kutsutaan tuttavallisemmin holokaustiksi. Nykypäivänä holokaustiin suhtaudutaan hyvin surullisissa mielissä ja siitä on puhuttu eri paljon negativiviseen sävyyn. Kansallissosialismin kannatus on laskenut huimasti toisen maailmansodan jälkeen. Aikalailla kaikkia kansallissosialisteja vihataan siitä, mitä juutalaisille tehtiin 40-luvun Euroopassa. Toki uusnatsismi on noussut nykypäivänä suuresti Yhdysvalloissa ja Euroopassa, johtuen Euroopan todella huonosta yhteisestä maahanmuuttopolitiikasta. (Essee C) 
Opettajat kommentoivat esimerkissä 13 olevaa esseen C kohtaa runsaasti. Esimerkiksi Suvi kommentoi: kakkoskysymykseen on vastattu jollain aika aatteellisella sävyllä mistä ehkä tulee tän kakkoskysymyksen ongelma että se on vähän tommonen moralistinen ja niinkun poliittinen kysymys [- -] aika vahvaan väitteeseen lopettaa ja toivoisin sille niinkun lisää perusteluja. Tarkemman kielellisen analyysin perusteella paljastui, että esimerkin 13 essee eroaa interpersoonaisten piirteiden perusteella monista muista esseistä - erityisesti siinä, millaista asennoitumista siinä ilmaistaan. Tekstiin muodostuu niin sanottu arvottajan ääni, jolle historian pohtivissa esseevastauksissa ovat tyypillisiä affektiiviset ilmaukset ja voimakkaat arviot (esim. äärimmäisessä ja hirveimmässä, hyvin surullisissa mielissä, kaikkia kansallissosialisteja) (Paldanius, 2020, s. 43).

Haastattelujen perusteella opettajat arvostivat pohtivaa ja moninäkökulmaista kannanoton ja vastauksen esittämistapaa. Esimerkiksi Ramin mukaan esimerkissä 13 esitellyn esseen $\mathrm{C}$ pohdinta onnistuisi paremmin, jos siinä osattaisiin ottaa esille erilaisia just näitä miten eri maissa on esimerkiks nyt suhtauduttu nykypäivänä tai miten eri poliittisissa suuntauksissa just suhtaudutaan siihen holokaustiin. Parhaaksi arvioidussa esseessä D (esimerkki 14) onnistutaan tässä:

14. Monet maat ovat haluttomia kieltämään [po. myöntämään], että osallistuivat holokaustiin. Haluttomuus saatetaan viedä niinkin pitkälle, ettei edes haluta aloittaa tutkimusta asian selvittämiseksi: tuloksia pelätään. Holokaustin myöntämisellä olisi kuitenkin merkitystä uhreille. Holokausti saattaa edelleen painaa joidenkin ihmisten suvuissa. Holokaustista kärsineiden lisäksi asia saattaa painaa niitä, joiden sukulainen oli osa puoluetta. Nykyään pitäisi kunnioittaa kuolleiden muistoa, mutta samalla ymmärtää, että teosta on jo aikaa ja nykyiset saksalaiset eivät oikeastaan enää ole vastuussa siitä. Historiasta voidaan ottaa myös opiksi. (Essee D)

Tomin mukaan essee D on kohtalaisen hyvä ja jopa niinkun jossain mielessä oivaltava koska se käsittelee tätä aihepiiriä vähän niinkun useammalta kantilta jopa eli siinä niinkun viitataan tähän että tota näen että nykysaksalaiset eivät enää ole vastuussa tästä asiasta. Kielen piirteistä huomiota kiinnittävät taas erityisesti interpersoonaiset piirteet: Esimerkkiin 13 verrattuna tässä esimerkissä arviot eivät ole voimakkaita, vaan päinvastoin niiden ehdottomuutta loivennetaan modaalisten ilmausten avulla (saatetaan viedä niinkin pitkälle, oikeastaan). Kannanotot esitetään konditionaalissa (olisi kuitenkin merkitystä, pitäisi kunnioittaa) ja niitä perustellaan. Lisäksi esimerkissä näkyy useampien näkökulmien huomioon ottaminen (esim. myönnytystä ilmaiseva mutta). Tekstiin rakentuu analysoiva kirjoittajaääni, joka on tyypillinen erityisesti selittäville historian teksteille (Coffin, 2006, s. 154-156) ja jota voidaan pitää esimerkin 13 arvottajan ääntä pohtivampana (Paldanius, 2020, s. 50).

\section{Pohdinta}

Tässä tutkimuksessa tarkastelimme, millaisia piirteitä historian opettajat arvostavat aineistopohjaisissa esseissä ja kuinka nämä piirteet konkretisoituvat kielellisesti aineistopohjaisissa esseissä. Tulokset osoittavat, että 
opettajien arvostamissa piirteissä korostuivat erityisesti sisältötiedon hallintaan liittyvät seikat sekä tehtävänannon noudattaminen. Sen sijaan aineiston käyttöön ja erityisesti opiskelijan omaan pohdintaan liittyviä odotuksia opettajilla oli kertomansa mukaan vähemmän. Sisältötiedon hallinnan kannalta ensisijaiseksi nousi tehtävän kannalta olennaisen historiatiedon esittäminen sekä tiedonalan käsitteiden käyttö. Nämä painotukset ovat yhteneväisiä historian opetusta koskevien tutkimusten kanssa, joiden mukaan sisältöpainotteisuudella on edelleen vahva asema historian opetuksessa (Rantala, Puustinen, Khawaja, van den Berg \& Ouakrim-Soivio, 2020; Sulkunen \& Saario, 2019).

Sisältöpainotteisuudesta huolimatta opettajat kertoivat arvostavansa myös tiedonmuodostuksen ja historiallisen ajattelun käytänteisiin liittyviä piirteitä, jotka kohdistuivat aineiston käyttöön ja pohdintaan. Näistä tiedonalan tekstitaitoihin (Moje, 2015) kiinnittyvistä piirteistä aineiston lähdekriittinen tarkastelu ja siihen perustuva tulkinta oli keskeisin, joskin myös aineiston kytkeminen historiatietoon ja laajempiin historian ilmiöihin nousi esiin. Pohdinnan esittämiseen liittyviä odotuksia opettajat mainitsivat vähiten, ja odotukset kohdistuivat lähinnä oman näkemyksen esittämisen tapaan eli interpersoonaisiin merkityksiin. Tämän tutkimuksen tulokset ovat osittain yhteneviä aiemman kansainvälisen tutkimuksen kanssa: esimerkiksi historian opettajien käsityksiä tarkastellut de Oliveira (2011, s. 83-84) havaitsi, että opettajat arvostavat esseessä ennen kaikkea oikeanlaisen sisällön hallintaa ja argumentoivassa esseessä selkeää argumentointia ja kannanottoa.

Tehtävänannon noudattamisessa opettajat pitivät tärkeinä kaikkiin tehtävänannon kysymyksiin vastaamista sekä aineiston hyödyntämistä vastauksessa. Lisäksi he kertoivat arvostavansa selkeän ja johdonmukaisen tekstin rakentamisen taitoa. Tekstin rakenteen selkeys on korostunut myös aiemmassa tutkimuksessa (de Oliveira, 2011). Tehtävänannon noudattamiseen ja tekstin rakenteeseen liittyvät valmiudet ovat osa yleisiä vastaustaitoja missä tahansa oppiaineessa. Tällaisten perusvaatimusten korostuminen on näkynyt myös aiemmassa tutkimuksessa, jossa on todettu, että aineenopettajat tyypillisesti antavat palautetta koko tekstistä suhteessa tehtävänantoon (Humphrey ym., 2010). Nämä perusvaatimukset eivät kuitenkaan vielä eksplikoi kirjoitettavaan tekstilajiin liittyviä odotuksia.

Haastattelujen yhdistäminen esseiden ideationaalisten ja tekstuaalisten piirteiden analysointiin paljasti, että haastatteluissa keskeiseksi muodostuva historian sisältötiedon esittäminen realisoituu esseissä erityisen hyvin silloin, kun tekstissä osoitetaan historian kielen ja esitystapojen hallintaa: historian käsitteiden käyttöä, abstraktien toimijoiden ja toiminnan esittämistä ja analyyttista asioiden suhteuttamista toisiinsa. Myös johdonmukaisesti etenevän ja sujuvan asiatekstin kirjoittamisen taito nousi opettajien haastatteluissa esiin yhtenä historian tekstitaitoihin liittyvänä piirteenä. Kielellisestä näkökulmasta sujuvuus liittyy tekstuaaliseen metafunktioon ja informaation kulkuun tekstissä eli siihen, kuinka tekstissä lukijalle tuttu ja uusi tieto esitetään ja kytketään toisiinsa (Shore, 2008).

Kielellinen analyysi osoitti, että myös interpersoonaisilla piirteillä on vaikutusta tekstin arviointiin: Sangen kevyt viittaaminen lähdeaineis- 
toon riittää täyttämään opettajien odotukset tehtävänannon noudattamisesta. Parhaisiin pisteisiin opettajien mukaan kuitenkin yltää vasta, jos osoittaa taitoa tulkita aineistoa historian tiedonalalle ominaisella tavalla. Tarkastelemiemme esseiden tehtävänantoon kuuluvan aineiston kohdalla tulkinta tarkoittaa esimerkiksi runon tekstilajin huomioimista ja lähdeaineiston tuottajan intentioiden pohdintaa. Toisin sanoen mekaanisen viittaustekniikan hallinta ei riitä, vaan opiskelijan tulisi osata eksplikoida tekstilajin taustatietoja sekä päätelmiä, jotka näistä tiedoista voidaan historian kontekstitiedon perusteella johtaa.

Vaatimus kiinnittää aineistosta tehdyt havainnot juuri historian kontekstitietoon tukee aikaisemman tutkimuksen tuloksia siitä, että aineistojen pohjalta kirjoittaminen on historian oppiaineessa joiltain osin omanlaistaan eli tiedonalakohtaista (Moje, 2015; Paldanius, 2019). Analyysi osoitti myös, että pohtivaa lähestymistapaa edellyttävässä tehtävänannossa opiskelijan tulisi hallita historian kielen ja loogisesti etenevän tekstin kirjoittamisen lisäksi oikeanlainen tapa ilmaista omia näkökulmia ja kannanottoja. Opettajat painottivat, että historiassa vastaus ei saa perustua mielipiteeseen, vaan sen muodostamisessa tulee hyödyntää historiatietoa. Tämä tulos on yhtenevä aiemman tutkimuksen kanssa: historian vastausten kirjoittamisessa oleellista on taito argumentoida asiapohjaisesti (Paldanius, 2020).

Tutkimuksemme on pienimuotoinen, eikä sen perusteella voi tehdä yleistyksiä kaikkien historian opettajien aineistopohjaiselle esseelle asettamista odotuksista. Tuloksemme ovat kuitenkin yhteneviä aiemman historian opetusta koskevan tutkimuksen kanssa (de Oliveira, 2011; Rantala ym., 2020; Sulkunen \& Saario, 2019), mikä validoi havaintomme sisältöjen painottamisesta opetuksessa sekä kielellisten odotusten vähäisestä eksplikoimisesta aineenopetuksessa (Humphrey ym., 2010; Pessoa ym., 2017). Yhdistimme tutkimuksessamme opettajien haastatteluaineiston analyysin sekä esseiden kielellisten valintojen analyysin, mitä ei suomalaisessa tutkimuksessa juuri ole tehty. Vaikka näiden kahden aineiston väliset yhteydet ovat tutkijoiden tulkintoja, vahvisti tulkintojamme keskittyminen niihin esseiden piirteisiin ja kohtiin, joihin opettajat suoraan viittasivat haastatteluissa. Saimme systeemis-funktionaalisen kieliteorian menetelmien avulla näkyviin eri merkitystasojen painon kunkin haastatteluissa esiin nousseen temaattisen kategorian sisällä. Metafunktioiden analyysi mahdollisti vertailun aikaisempaan historian esseiden kielelliseen analyysiin (Paldanius, 2019, 2020; de Oliveira, 2011), josta saimme vahvistusta tuloksillemme.

Tämän tutkimuksen tulosten perusteella voi pohtia, missä määrin opettajien arvostamat piirteet ovat tiedonalakohtaisia ja missä määrin ne edustavat yleisempiä opiskelun tekstitaitoja, joita ovat esimerkiksi sopiva käsitteellisyyden aste, asioiden suhteuttaminen toisiinsa, asiatyylin hallinta ja aineistojen oikeaoppinen käyttö (Schleppegrell, 2004). Tiedonalakohtaisuus muodostuu siitä, että yleiset tekstitaidot kietoutuvat tiedonalan tiedon muodostamisen ja esittämisen tapoihin. Historian tiedonalalla käsitteellisyys liittyy relevanttien historian käsitteiden käyttöön ja asioiden suhteuttamisessa olennaista on ilmaista ajallisia sekä syy-seuraussuhteita. Tiedon tulkinnallinen luonne taas edellyttää, että kirjoittaja lieventää väitteidensä ehdottomuutta esimerkiksi modaalisten 


\section{Ainedidaktiikka 5(1) (2021)}

ilmausten avulla. Kaikki tämä on osa historian esitystapojen hallintaa. Sen sijaan esimerkiksi luonnontieteissä painottuvat luokittelut ja käsitehierarkiat sekä empiiriset havainnot, joiden pohjalta tehtäviä päätelmiä ei ole tarpeen samalla tavoin lieventää (Goldman ym., 2016).

Edellä sanotun pohjalta voi todeta, että kunkin oppiaineen opettajan asiantuntemus tiedonmuodostuksen ja esittämisen käytänteistä on tarpeen, kun konkretisoidaan ja tehdään näkyväksi tiedonalan vaatimuksia kulloinkin kirjoitettavassa tekstilajissa ja opetetaan aineistojen tulkinnan taitoja tiedonmuodostuksen näkökulmasta. Niin tämä kuin aiemmat tutkimukset (esim. Humphrey ym., 2010; Pessoa ym., 2017) antavat viitteitä siitä, ettei aineenopettajilla ole kovin hyviä valmiuksia eritellä arvostamiaan kielellisiä piirteitä: tässä tutkimuksessa se näkyi esimerkiksi vaikeutena konkretisoida esittämistapaan liittyviä piirteitä, kuten sujuvuutta. Tämän vuoksi olisi tiedonalan kirjoittamisen opettamisen näkökulmasta tärkeää, että aineenopettajat ja kielelliseen analyysiin harjaantuneet (äidinkielen) opettajat tekisivät yhteistyötä. Tähän uusien lukion opetussuunnitelman perusteiden (Opetushallitus, 2019) moduulirakenne antaa mainiot mahdollisuudet. Toki myös opettajien koulutus kaipaa kielitietoisuuteen ja tiedonalan kieleen liittyviä sisältöjä.

Tutkimus on kirjoitettu osana Suomen Akatemian rahoittamaa konsortiota "Kohti tiedonalakohtaista ajattelua lukiossa: Historian tekstitaitojen hallinta, oppiminen ja arviointi”, projektinumero 294487.

\section{Lähteet}

Barton, D. (2007). Literacy. An introduction to the ecology of written language. Malden: Blackwell.

Coffin, C. (2006). Historical discourse. The language of time, cause and evaluation. London: Continuum.

De Oliveira, L. (2011). Knowing and writing school history. The language of students' expository writing and teachers' expectations. Purdue University: Information Age.

Goldman, S. R., Britt, M. A., Brown, W., Cribb, G., George, M., Greenleaf, C., Lee, C. D., Shanahan, C. \& Project READI. (2016). Disciplinary literacies and learning to read for understanding: A conceptual framework for disciplinary literacy. Educational Psychologist, 51(2), 219-246. https://doi.org/10.1080/00461520.2016.1168741

Halldén, O. (1998). Personalization in historical description and explanations. Learning and Instruction, 8(2), 131-139. https://doi.org/10.1016/S0959-4752(97)00012-1

Halliday, M. A. K. (1973). Explorations in the functions of language. London: Arnold.

Halliday, M. A. K. \& Martin, J. R. (1993). Writing science. Literacy and discursive power. Pittsburg: University of Pittsburg Press.

Humphrey, S., Martin, J. R., Dreyfus, S. \& Mahboob, A. (2010). The 3x3: Setting up a linguistic toolbox for teaching and assessing academic writing. Teoksessa A. Mahboob \& N. Knight (toim.), Applicable linguistics: Texts, contexts and meanings (s. 185-199). London: Continuum. 


\section{Ainedidaktiikka 5(1) (2021)}

Juvonen, R. (2014). Näkökulma kirjoitelman dialogisuuteen. Kuinka- ja miten-yhdyslauseet ylioppilasaineessa. Virittäjä, 118(1), 72-106. https://journal.fi/virittaja/article/view/8759

Karvonen, P. (1995). Oppikirjateksti toimintana. Suomalaisen Kirjallisuuden Seuran toimituksia 632. Helsinki: Suomalaisen Kirjallisuuden Seura.

Luukka, M.-R. (2004). Genre-pedagogiikka: askelia tekstitaitojen jatkumolla. Teoksessa M.-R. Luukka \& P. Jääskeläinen (toim.), Hiiden hirveä hiihtämässä: hirveä(n) ihana kirjoittamisen opetus. Äidinkielen opettajain liiton vuosikirja 2004 (s. 145160). Helsinki: Äidinkielen opettajain liitto.

Martin, J. R. \& Rose, D. (2008). Genre relations. Mapping culture. London: Equinox.

Mayring, P. (2000). Qualitative Content Analysis. Forum: Qualitative social research, 1(2), 20. https://doi.org/10.17169/fqs-1.2.1089

Moje, E. B. (2015). Doing and teaching disciplinary literacy with adolescent learners: A social and cultural enterprise. Harvard Educational Review, 85(2), 254-279. https://doi.org/10.17763/0017-8055.85.2.254

Nokes, J.D. (2013). Building students' historical literacies. Learning to read and reason with historical texts and evidence. London: Routledge. https://doi.org/10.4324/9780203137321

Opetushallitus (2015). Lukion opetussuunnitelman perusteet 2015. Helsinki: Opetushallitus.

Opetushallitus (2019). Lukion opetussuunnitelman perusteet 2019. Helsinki: Opetushallitus.

Paldanius, H. (2019). Selostuksesta tulkintoihin: aineistojen esittäminen lukiolaisten historian esseissä. Virittäjä, 123(3), 347-372. https://doi.org/10.23982/vir.70430

Paldanius, H. (2020). Kuinka pohtivuutta edellyttävään tehtävänantoon vastataan? Erilaiset kirjoittajaäänet lukiolaisten historian esseissä. Kasvatus \& Aika, 14(2) 35-56. $\underline{\text { https://doi.org/10.33350/ka.84069 }}$

Pessoa, S., Mitchell, T. D., \& Miller, R. T. (2017). Emergent arguments: A functional approach to analyzing student challenges with the argument genre. Journal of Second Language Writing, 38, 42-55. https://doi.org/10.1016/i.jslw.2017.10.013

Pietilä, I. (2017). Ryhmäkeskustelu. Teoksessa M. Hyvärinen, P. Nikander \& J. Ruusuvuori (toim.), Tutkimushaastattelun käsikirja (s. 111-130). Tampere: Vastapaino.

Puustinen, M., Paldanius, H. \& Luukka, M.-R. (2020). Sisältötiedon toistamista vai aineiston analyysia? Tiedonalakohtaiset tekstitaidot historian ylioppilaskokeen tehtävänannoissa ja pisteytysohjeissa. Kasvatus \& Aika, 14(2), 9-34. https://doi.org/10.33350/ka.84579

Rantala, J. \& van den Berg, M. (2015). Finnish high school and university students' ability to handle multiple source documents in history. Historical Encounters, 2(1), 70-88. http://hej.hermes-history.net/index.php/HEJ/article/view/50

Rantala, J., Puustinen, M., Khawaja, A., van den Berg, M. \& Ouakrim-Soivio, N. (2020). Näinkö historiaa opitaan? Helsinki: Gaudeamus.

Schleppegrell, M. J. (2004). The Language of Schooling. A Functional Linguistic Perspective. London: Lawrence Erlbaum Associates. https://doi.org/10.4324/9781410610317

Schreier, M. (2013). Qualitative Content Analysis. Teoksessa U. Flick (toim.), The SAGE Handbook of Qualitative Data Analysis (s. 170-183). London: Sage. https://doi.org/10.4135/9781446282243.n12

Shore, S. (2008). Lauseiden tekstuaalisesta jäsennyksestä. Virittäjä, 112(1), 24-65. https://journal.fi/virittaja/article/view/40639

Shore, S. (2012). Kieli, kielenkäyttö ja sen lajit systeemis-funktionaalisessa teoriassa. Teoksessa V. Heikkinen, E. Voutilainen, P. Lauerma, U. Tiililä \& M. Lounela (toim.), Genre-analyysi. Tekstilajitutkimuksen käsikirja (s. 131-157). Helsinki: Gaudeamus.

Sulkunen, S., Luukka, M.-R., Saario, J. \& Veistämö, T. (2019). Monilukutaito historian opetuksessa. Ainedidaktiikka, 3(2), 2-23. https://doi.org/10.23988/ad.76111

Sulkunen, S. \& Saario, J. (2019). Tiedonmuodostus ja tekstityö: tapaustutkimus lukion historian opetuksen tekstikäytänteistä. Kasvatus, 50(2), 149-163.

Tutkimuseettinen neuvottelukunta (2019). Ihmiseen kohdistuvan tutkimuksen eettiset periaatteet ja ihmistieteiden eettinen ennakkoarviointi Suomessa. Tutkimuseettisen neuvottelukunnan ohje 2019. Helsinki: Tutkimuseettinen neuvottelukunta. 


\section{Ainedidaktiikka 5(1) (2021)}

Veijola, A. (2016). Nuoret ja historian tekstitaidot. Tiedon vastaanottamisesta käsittelyyn ja käyttämiseen. Nuorisotutkimus, 34(3), 3-18. http://urn.fi/URN:NBN:fi:ELE-016777388

Veijola, A. \& Mikkonen, S. (2016). Historical literacy and contradictory evidence in Finnish high school setting: The Bronze soldier of Tallin. Historical Encounters, 3(1), 1-16.

http://hej.hermes-history.net/index.php/HEJ/article/view/52

Virta, A. (1995). Abiturientin historian ja yhteiskuntaopin tieto: reaalikoevastaukset oppilaiden tiedonrakenteiden ja tiedon laadun ilmentäjinä. (Väitöskirja). Turun yliopisto.

Ylioppilastutkintolautakunta 2015 = Historian koe 11.3.2015. Hyvän vastauksen piirteitä. Ylioppilastutkintolautakunta. 